\title{
Elite Consensus on the Norwegian Welfare State Model
}

Published in West European Politics, 2005 Vol. 28 (4): 898 - 918

TRYGVE GULBRANDSEN, Institute for Social Research

t.j.gulbrandsen@sosiologi.uio.no

FREDRIK ENGELSTAD, Institute for Social Research

fredrik.engelstad@samfunnsforskning.no

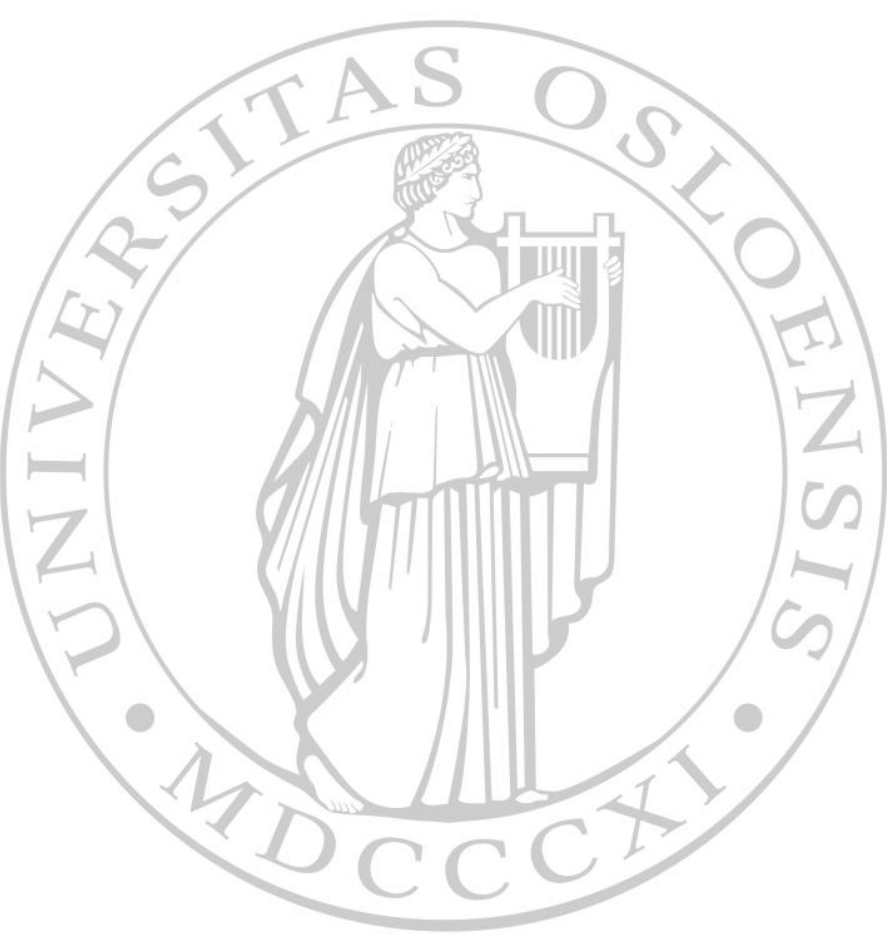

Department of Sociology and Human Geography University of Oslo

P.O.Box 1096 Blindern

N-0317 OSLO Norway

Telephone: $\quad+4722855257$

Fax: $\quad+4722855253$

Internet: http://www.iss.uio.no 


\title{
Elite Consensus on the Norwegian Welfare State Model
}

\author{
TRYGVE GULBRANDSEN AND FREDRIK ENGELSTAD \\ Institute for Social Research, Oslo
}

\begin{abstract}
Is the Norwegian welfare state model under pressure? In this article we argue that this model will persist to the extent that there is a relatively strong consensus among the majority of the national elites to support it. The empirical results presented indicate that the majority of the Norwegian elites at the time of the study (2000) supported the basic institutions and policies in the model and the political compromises upon which they are based. They express strong support for the system of centralised wage settlements, a main element in the industrial relations system. They rally behind continued economic transfers to the rural areas. A majority (albeit small) of the elite groups prefers to uphold the present state model of production and distribution of welfare services. There are, however, differences between the various elite groups as to how they view the welfare state model. While the members of the private business elite express preference for basic changes, the mass media elite, the academic elite and the church leaders are clearly in favour of the present model. The opinions of the individual leaders are particularly related to the elite groups to which they belong. Social and educational background has much less effect upon their attitudes.
\end{abstract}

\section{Introduction}

Since the early 1990s the Scandinavian welfare state model has been under attack, and particularly so the Swedish version of the model. Due to its oil revenues, prospects for the Norwegian welfare state have been regarded as brighter than those of its Swedish neighbour. Nevertheless, there are signs that the Norwegian version may face a difficult future as well. Changes which have taken place during the last decades have limited the field of political action in decisive ways, as pointed out by the Power and Democracy Study (Østerud et al. 2003). The most important of these are changes connected to internationalisation: international agreements above all the EEA agreement - restrict the scope of action of public authorities. Increasing mobility of capital across borders has forced national authorities to pay more heed to the international finance market while at the 
same time the market is increasingly seen as a legitimate and effective mechanism for governing and regulating public as well as private activities.

These changes obviously pose great challenges to the model, but they do not have as a necessary consequence that the Norwegian welfare state system is abolished. An in-depth analysis of the relationship between economic performance and the welfare state indicates that the most important threats to the welfare state do not stem from internationalisation per se. Rather, they come from within, from protests against significant elements of the system, for instance against the relatively egalitarian income structure (Barth et al. 2003).

Against this background we discuss the degree of support from the national elites for the continuance of the model. Our basic assumption is that this model will persist to the extent that there is a relatively strong consensus among the majority of the national elites to support it, combined with a relatively small social distance between the elites and the population at large.

\section{Elites in Democratic Societies}

Classical elite theory developed from a general distrust of democracy (Mosca, Pareto), and of the possibility to maintain democratic institutions (Michels). Mills (1956) supplemented the classical elite theory by conceiving public and private elites as converging into a single ruling group in society.

Classical elite theories are not quite relevant for the description of a Western democracy such as Norway (Gulbrandsen et al. 2002). Elites do not disappear in democracy, but they acquire a new meaning. In recent elite theory (Lijphart 1969a, 1969b; Presthus 1973; Putnam 1976; Higley and Burton 1989) elites are described as institutionally distinct, socially disparate and politically diverse groups of national leaders. Mutual accommodation, compromises and consensus between these elite groups are seen as preconditions for the continuance and stability of democracies.

In our analysis, using the same framework, elites are defined as the holders of top positions in central institutions and organisations within significant sectors of the Norwegian society, for instance the political system, the economy and cultural life. As holders of leadership positions these elites act as representatives of the interests and concerns embodied in the particular institutions or organisations. They have been delegated power to act on behalf of the principals of the individual institutions, to whom they are responsible. Members of parliament are, for instance, responsible to the voters, senior civil servants to the elected politicians, union leaders to the union members, and private business leaders to the shareholders. Through processes of selection and socialisation the institutions and their principals ensure that the persons entering the top leadership positions are familiar 
with and have internalised the values and interests which the institutions are embodying.

Because the institutions stand for different concerns and interests, the various elite groups are prevented from automatically converging into a single ruling group. As observed already by Putnam (1976), much of the variation in outlook within modern elites is related to role differences. A national elite is constituted to the degree that sector elites are united, holding common interests and similar world views. However, this is not a sufficient condition for the constitution of a 'power elite' as envisaged by Mills (1956), as this also included an isolation of the elite from the general population.

The Norwegian welfare state model rests on a consensus grown out of previous class compromises, and compromises between opposing interest groups. The compromises were forged between the leaders of the various class and interest organisations or movements. In that sense, and in accordance with modern elite theories, these compromises were elite compromises.

The basic structure of Norwegian elite compromises has been brought out as a series of secondary, sector-specific compromises based on the primary compromise connected to the establishment of democratic governance (Engelstad et al. 1999). Throughout Norwegian history these sector-specific compromises may be found in such different spheres as working life, the relationship between centre and periphery, foreign policy, gender relations, the relationship between the state church and low church congregations (Gulbrandsen et al. 2002).

If elites are defined on the basis of social sectors, it may be argued that they are mainly powerless, as they only react to the demands and constraints of their given positions. However, in societies undergoing continuous change, actions of the top power-holders do make a difference. Not only do they affect the direction of their own institutions, they also may impinge upon the operations of other institutions and organisations. Even if their power is to some extent circumscribed by various mechanisms for monitoring and sanctioning their behaviour, the elites nonetheless enjoy substantial room for manoeuvre. Hence, decisions and actions by elites may have significant consequences for social development.

At the same time, elites in a modern democracy are not acting unconstrained by what is going on in other parts of society. In fact, there are several interdependencies between the various institutions. The institutional fabric of society bears resemblance to an ecological system: the promotion of particular institutional interests may depend upon the functioning of the other institutions. Private business, for instance, is highly dependent upon a large number of collective goods provided by the political system. To some extent the elites have to develop and shoulder responsibility for the general system of institutions as well. As a result, their 
actions may be more concerted than their immediate institutional interests and values would seem to imply.

The significance of the elites' attitudes to the continuance of the Norwegian model, and their ability to strike stable compromises, depends not only on their internal relationship, but also on the relationship between elites and the population at large. If the elites attempt to preserve or change the model independently of the opinions of the citizens, it may create masslevel reactions which may curtail or abort the actions of the elites. Relatively open processes of recruitment to the elites may bring the attitudes and opinions of the elites more in line with those of the population.

The elites' commitment to the Norwegian welfare state model and the historical compromises upon which it is founded must also be considered in the context of the overall elite structure, particularly the composition of the set of dominating elites. Throughout the twentieth century there have been significant changes in this aspect of the Norwegian elite structure. This point is illustrated in a Norwegian elite study from the late 1960s (Higley et al. 1975). This study restricted itself to four elite groups - the business elite, civil servants, politicians, and labour union leaders. With the enormous expansion of the media, cultural life, and research and university sector in the last decades, the set of dominant elites has become much broader. This also affects the power structure, putting increased weight on argumentation and ability of mass persuasion. Hence, the formation of a majority of elite groups supporting the Norwegian model will also depend upon the opinions of these 'new' elite groups.

\section{Mechanisms Affecting Elite Support for the Norwegian Model}

In order to investigate the elites' attitudes to the Norwegian model we focus on three areas where the present policies are the result of a series of historical elite compromises: (a) economic regulation, redistribution and welfare production by the state, (b) the relation between centre and periphery, i.e. the rural districts, and (c) industrial relations. As is made clear in the introductory article to this issue, these are significant aspects of the Norwegian model.

Elite support for the Norwegian model is not primarily a question of the average level of support, but of the distribution of support among different groups. We will therefore compare the attitudes of 12 different elite groups, all of them representing important institutions and sectors in Norwegian society. This comparison will enable us to identify what we may describe as alliances in favour of or against the three sets of policies.

The attitudes of the various elite groups towards the Norwegian welfare state model are, however, aggregations of the opinions of the individual members within each elite group. We will also discuss and empirically examine circumstances and mechanisms which influence the views of the individual top leaders. Significant changes in these circumstances may 
produce a sway of opinion among the members of a particular group such that the group as a whole changes its evaluation of the Norwegian model. We will focus upon four such mechanisms which foster or weaken individual elite members' support for the basic compromises in Norwegian society. In addition to elite position connected to sector, we focus upon class background, contact with representatives of other elite groups, and international contacts.

\section{Elite Position and Sector}

In general, we hypothesise that the degree of adherence to the Norwegian model is influenced by professional outlook, routines and interests (Putnam 1976). From the definition of elites given above, it follows that sector membership has similar differentiating effects. To give a simple example, social security to the businessman is an unwanted expenditure that he may wish to avoid; to the politician, voting for social policies is a precondition for being re-elected. However, to the degree that the Norwegian model has developed through a series of elite compromises, these differences are expected to be moderate.

\section{Class Background}

Historically, welfare state policies have raised the standard of living of the lower class and reduced income inequalities. Hence, it is expected that top leaders whose origins lie in working class and middle classes families particularly appreciate the Norwegian welfare state model. Members of the upper and upper middle classes also have benefited from the development of the welfare state, for instance in the form of high quality public health service, free education, and protection of the environment. The variations as to ideological views between top leaders from different classes are therefore probably moderate.

\section{Participation in the Corporatist System of Political Decision-Making}

Several scholars have suggested that corporatist arrangements may contribute to a national consensus between groups with opposing interests (Katzenstein 1985; Woldendorp 1995; Siaroff 1999; Öberg 2002). By participating in public committees and boards they learn to appreciate the functions and operations of the state and become less inclined to react on the basis of ideological standpoints. Moreover, corporatist arrangements bring members of different elite groups into personal contact with each other, thereby fostering a mutual understanding of each others' beliefs. On the other hand, those who do participate in public committees do so as representatives of interest groups, something that weakens the assumed effects. 


\section{Internationalisation}

As Norway is a small country with an open economy, top leaders in Norway have to be active on the international scene - in economic as well as in political relations. On average they spend ten per cent of their working hours in contact with organisations and individuals in other countries (Gulbrandsen et al. 2002). As members of international elite networks they are unavoidably exposed to values, norms and ideas which predominate in these networks and which, to a large extent, stand in contrast to the Scandinavian mode of thinking. But international contacts may also heighten the awareness of national interests and concomitantly move some to a stronger support of the particular institutions of the Norwegian society.

\section{Data and Variables}

Data on Norwegian elites were collected through a large and unique survey study of Norwegian economic, political and social elites, the Norwegian Leadership Study, which was carried out in the year $2000 .{ }^{1}$ The gross sample of 1,969 persons was established by the 'position method'. It included all persons in top positions in the 12 sectors outlined below. Data were collected through personal interviews with 1,710 of the leaders, giving a response rate of 87.3 per cent.

The Leadership Study is partly comparable to a Norwegian elite study carried out in the late 1960s (Higley et al. 1976). This study had a smaller sample and was restricted to four elite categories: business leaders, top civil servants, politicians and trade union leaders.

The three variables measuring support for the Norwegian model are constructed as follows. The attitudes of top leaders towards the traditional welfare state were measured by their opinions regarding (i) privatisation of public services, (ii) further development of the public sector vs. reduced taxes, and (iii) state intervention in private business. ${ }^{2}$

Evaluation of the centre/periphery dimension in Norwegian politics is examined by asking whether the leaders agree with the following statement: (i) 'The investments in road-building, bridges and tunnels in the local areas should be reduced', and through the following question: (ii) 'How important is it to maintain the level of economic transfers to the local areas in the years ahead? Is it very important, somewhat important, of little importance, or not important at all? ${ }^{3}$

To measure attitudes towards the system of centralised wage determination the leaders were asked the question: 'In your opinion, how important is it to Norway to continue the centralised wage settlements in the years to come?'

The central independent variables include the following:

- The groups of leaders, the sector membership, comprise the top positions in 12 sectors: (1) politicians, (2) state bureaucracy, (3) culture, (4) mass 
media, (5) private business, (6) the cooperative sector, (7) public business enterprises, (8) voluntary organisations, (9) universities and research institutes, (10) the legal system and the police, (11) the military, and (12) the church.

- Class of origin is constructed on the basis of information about the father's occupation, or mother's occupation where there is no information about the father. ${ }^{4}$ The class variable has three categories: (1) upper and upper middle classes, (2) middle class, and (3) working class.

- Participation in the corporatist system is measured in two ways. Firstly, we registered whether the leaders had been members of a public board or committee during the previous five-year period. Secondly, they answered a question about how frequently they had contact during the last year with members of a large set of other elite groups. ${ }^{5}$

- The top leaders' international contact is also measured in two ways. They were asked how much of their working time (percentage) is spent on contact with persons or organisations in other countries. Secondly they reported the two geographical areas of the world with which they have most contact. ${ }^{6}$

- In addition, three control variables are included: gender, age, which is a continuous variable, and level of education, which has eight values and is likewise treated as a continuous variable.

We start the analysis by establishing the social distance between the elites and the population at large. The next step is to describe the variation between sectors/elite groups in support of the Norwegian model. We then commence to examine the individual elite members' attitudes. In three regression (OLS) models we investigate the effects of the four independent variables and the three control variables. International comparisons are made when available data make it possible.

\section{Class Origin and Degree of Social Isolation of Norwegian Elites}

To what degree may the Norwegian elites be regarded as isolated from the population? The first two columns in Table 1 show the class of origin of the elite groups as a whole, and of the population in the same age groups, in 2001. The data show a recruitment pattern that is fairly open, but far from egalitarian. Whereas 58 per cent of the population have their origins in the working class/lower class, only 22 per cent among the elites have this social background. At the same time, 37 per cent of the elites have their background in the upper and upper middle classes compared to 10 per cent of the population. Concerning social background, Norwegian elites have quite good contacts with people far from their own positions.

An indication of the extent to which there has been an opening of elite positions is given in the remaining columns of Table 1, where elite recruitment in 2001 is compared to that of 1967 . The comparison is limited 
Elite Consensus on the Norwegian Welfare State Model 905

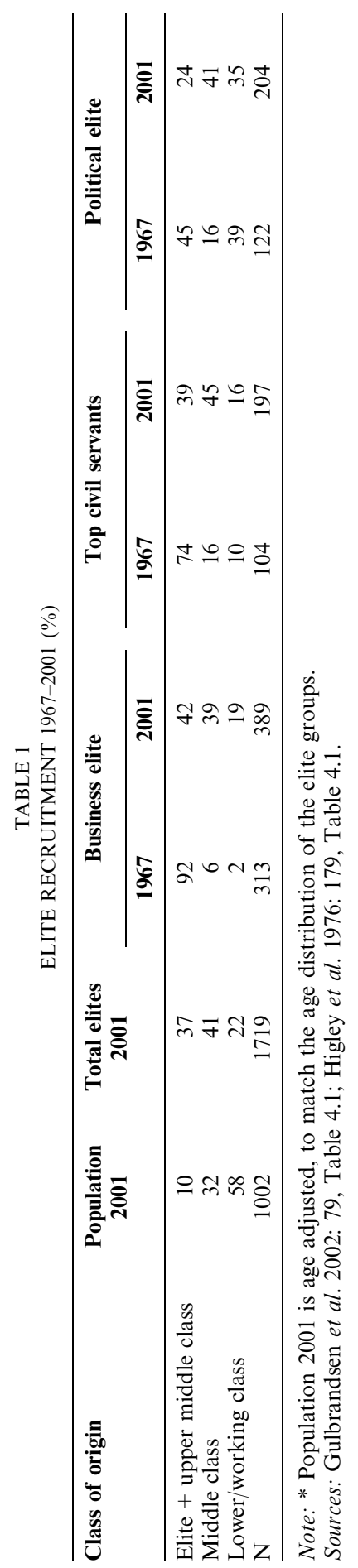


to those groups which were studied in both years. While as much as 92 per cent of the business elite in 1967 had elite or upper middle class backgrounds, only 42 per cent had fathers who belonged to the upper class and upper middle class in 2000. Significant decreases in the recruitment of elite members from the higher social strata of society appear among civil servants and politicians as well.

The comparison with 1967 should be treated with caution, as both sampling procedures and conceptualisation of social class differed in the two studies. ${ }^{7}$ However, despite these sources of error, the results of the comparison are robust and quite striking.

Thus, there can be no doubt that recruitment to traditional elite groups has become more open during the last decades of the twentieth century. The 'new' elites in 2001 which gained importance in the same period, i.e. those filling top positions in the media, research and cultural life, have a social background which is not significantly different to that shown for civil servants in 2001. They are all within the range of 2-3 percentage points from the group average of the total 2001 sample (Gulbrandsen et al. 2002, Table 4.1).

Available data from international comparisons indicate that the present pattern of elite recruitment in Norway is fairly typical in Northern Europe. As in Norway, the members of the political elite in Denmark, Sweden and Germany are more frequently recruited from the lower middle classes than the other elite groups (SOU 1990: 322; Schnapp 1997: 82; Christiansen et al. 2001: 217). In Finland, however, politicians are somewhat more often recruited from the upper and upper middle classes (Ruostersaari 1993: 315). In all countries private business leaders have on average a relatively privileged background. However, a higher percentage of business leaders in Norway and Finland come from families belonging to the upper or upper middle class than do the business leaders in Denmark and Sweden. Top leaders in the public administration in Germany are more frequently recruited from privileged classes than in the Nordic countries (Schnapp 1997: 82).

The degree of social isolation from the population may also be measured by differences in opinion. In general, the Norwegian population is in favour of government intervention to make incomes more equal and to guarantee living conditions (Listhaug and Aalberg 1999), more so than the elite. The elites do not, however, deviate much from the rest of the population. Previous analyses of the Leadership Study show that Norwegian elites are somewhat less concerned about reducing income inequalities, but more committed to equal opportunities for women and minority groups. The elite possess important similarities with the citizens in other respects as well. For instance, the percentage of members of the Norwegian elite who voted socialist in the 1997 parliamentary election is about the same as in the population as a whole. Moreover, the elite members are distributed along the same political cleavages as the citizens (Gulbrandsen et al. 2002). 


\section{Support for the Norwegian Model among Sector Elites}

We commence the analysis of elite support for the Norwegian model by presenting average mean scores of each sector elite group on the three indices. Figure 1 combines answers concerning the private/public and the centre/periphery issues. Along both axes the midpoint value is 2.5 , indicating moderate support.

Figure 1 shows, firstly, that along the private/public dimension (the $\mathrm{x}$ axis) the majority of the elite groups are clustered around the midpoint value. Six of the groups are located left of this value. They show moderate support for the welfare state model. Politicians, leaders of institutions within the culture sector, and church leaders, emerge as the strongest supporters of the present role and size of the public sector. Among the politicians the opinions are, however, quite divergent, following the stance of the individual political parties (cf. Figure 3 below). Five groups are located to the right of the midpoint value indicating that they counter this model. Four of these - top leaders in public business enterprises, in the military services, in enterprises within the cooperative sector and in the mass media - must, however, be characterised as moderate in their opposition. The exception is the private business leaders, who distinguish themselves by being clearly in favour of more privatisation and a halt to public welfare expenditures. The moderately positive 'middle group' consists of top leaders in voluntary organisations, in the police and the judicial system, senior public officials and top leaders in universities and research institutes.

In general, even if market liberalism has gained ground, manifesting itself in opposition to high taxes among the citizens, scepticism toward state

FIGURE 1

THE ELITE GROUPS' SUPPORT FOR PUBLIC/PRIVATE AND CENTRE/PERIPHERY COMPROMISES

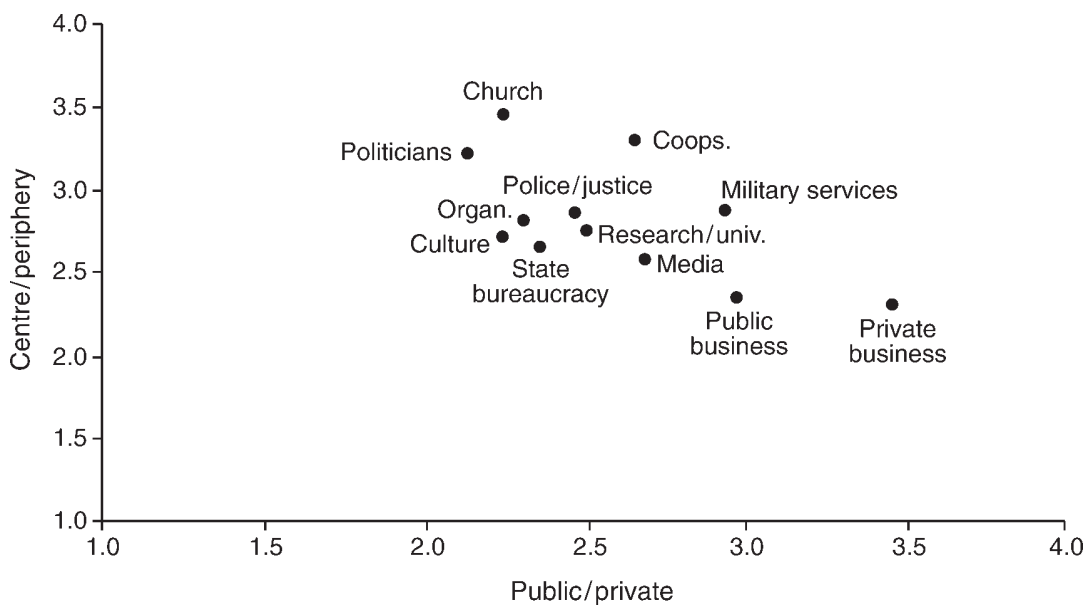


involvement among top business leaders, and measures for privatisation in politics, Figure 1 indicates that the support for the new ideological ideas among the Norwegian elites is still limited.

Secondly, Figure 1 demonstrates a stronger consensus among the Norwegian elite groups about the desirability of preserving the rural areas than to continue the state model of governance and welfare production (the $y$-axis). Ten of the elite groups are moderately to strongly in favour of continuing the economic transfers to the rural areas and to continue developing their infrastructure. We see this finding as an expression of a relatively broad support for the national centre/periphery compromises, stronger than for the private/public compromises. Only two of the 12 groups have mean values below the midpoint value. Church leaders are the most positive towards upholding vital rural areas; the private business leaders are the most negative. Nonetheless, the private business leaders are quite moderate in their opposition to continued regional development.

Thirdly, Figure 1 reveals clearly that the top leaders' attitudes towards the welfare state are relatively closely related to their views about the centre/ periphery compromises. Members of elite groups who are positive towards the public sector are also active supporters of the interests of the rural areas $(r=0.39)$. This applies particularly to the church leaders. At the other end of the scale we see that top leaders in both private and public business enterprises favour more privatisation and a reduction in the economic transfers to rural areas. Higher military officers break this pattern of similar location along the two indexes. They support active regional policies, but are at the same time sceptical of the role and responsibilities of the state.

Elite consensus is even stronger when it comes to aspects of industrial relations. Figure 2 demonstrates a generally strong backing of the

FIGURE 2

SUPPORT FOR CENTRALISED SYSTEM OF WAGE DETERMINATION (\%)

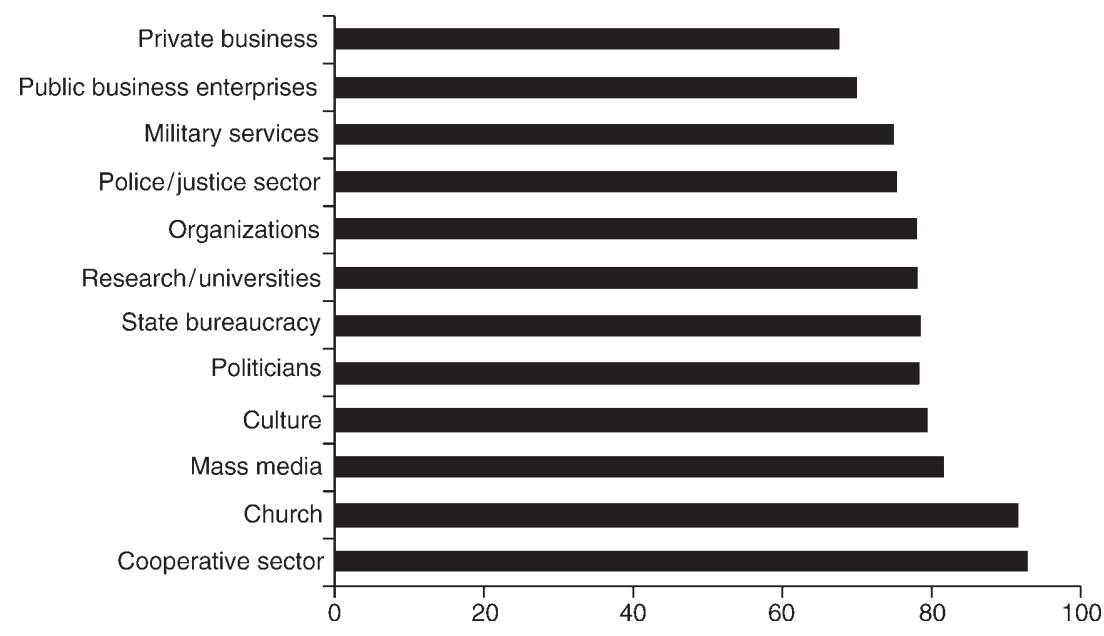


Norwegian system of centralised wage determination. Even among private business leaders, who are the least enthusiastic elite group, 69 per cent consider it important that Norway continues this way of settling the wages in the labour market. Leaders in firms within the cooperative sector and church leaders are those elite groups who are most positive towards this main element in the industrial relations system.

\section{Political Cleavages}

In order to assess the significance of elite consensus and conflict, the findings depicted in Figure 1 may be contrasted with the distribution among politicians in the parliament. Figure 3 shows that parliamentary members who belong to the Socialist People's Party $(S V)$, the Centre Party $(S p)$ and the Labour Party $(A p)$ are strongly in favour of the present state model, while members of the Conservative Party (Hoyre) and the (right-wing) Progress Party $(F r P)$ are strongly opposed to state intervention. The differences are less concerning the politicians' views upon policies for preserving rural areas. It is noticeable that all the parties in the Storting support subsidies for local areas.

Figure 3 indicates that the Conservative Party and the Progress Party are the most natural allies for the private business leaders in their resistance to state intervention and a large public sector. It should be noted that the members of these two parties actually declare themselves more in opposition to state intervention than private business leaders. The same is true for their views on industrial relations, as the Conservative Party and the Progress Party are more sceptical of centralised wage bargaining and work

FIGURE 3

SUPPORT FOR PUBLIC/PRIVATE AND CENTRE/PERIPHERY COMPROMISES AMONG MEMBERS OF PARLIAMENT

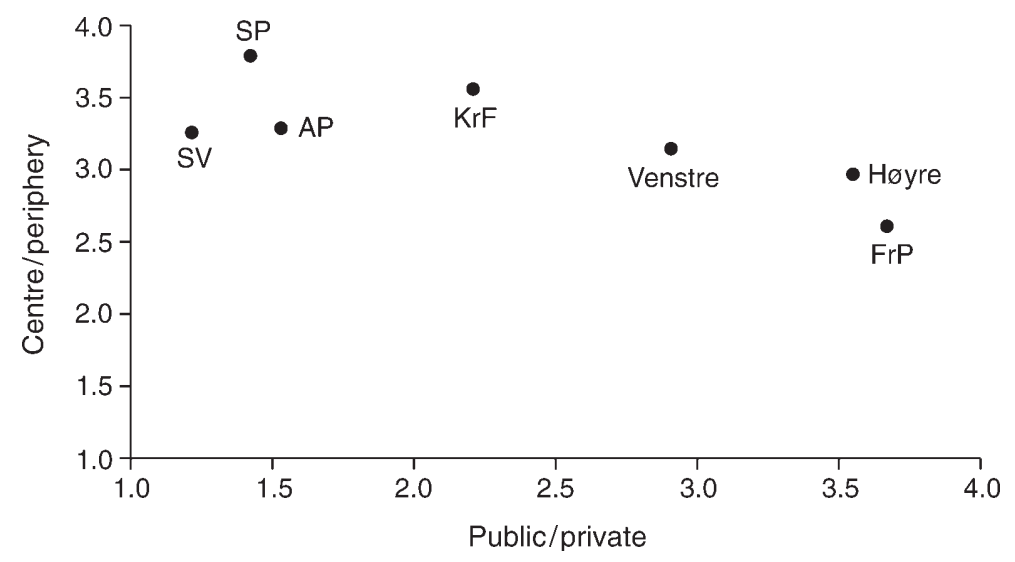


environment protection than are the business leaders (Gulbrandsen et al. 2002). Hence, manifest political cleavages do not necessarily reflect underlying conflicts among elites.

The two other elite groups which to a certain extent share the opinions of the private business leaders on state intervention - the elite within the military services and the top leaders in publicly owned business companies - are ideologically closer to the members of the Liberal Party (Venstre). Top leaders within the police and the judiciary, among whom many vote for the Conservative Party (Gulbrandsen et al. 2002), are quite far removed from the Conservative Party in their evaluation of the public sector.

\section{International Comparisons}

The few international elite studies which are comparable to the Norwegian study show clear similarities in opinions of various elite groups on significant issues. In a German elite study carried out in 1972 (HoffmanLange et al. 1985), politicians from the SPD and CDU/CSU represented the extreme points in the opinions concerning economic policy and social policy, whereas the administrative elite fell in the middle between the political parties, and the private business elite and the military elite stood close to the $\mathrm{CD} / \mathrm{CSU}$ on both issues. Top leaders within mass media and within science and higher education had a position similar to the SPD on social policies, but were between the political parties on matters of economic policy. The fact that the political parties hold more extreme positions is similar to the situation in Norway (see Figure 3).

In a Swedish elite study from the end of the 1980s (SOU 1990; Petersson et al. 1996) the private business elite distinguished itself from the other elite groups by giving lower priority to the public sector, equality and the environment (defined as a red/green dimension) and to immigration, development aid and social benefits (defined as a welfare dimension). Politicians and the cultural elite in Sweden were located in at the opposite end to the private business elite, being preoccupied with red/green issues and with supporting welfare policies, again similar to our findings. With reservations regarding different research designs, it seems that the private business elite in Sweden stands more apart from the other elite groups than the private business elite in Norway.

\section{Factors Explaining Adherence to the Welfare State}

To what extent are the differences between sector elites attributable to sector specificity, and to what extent are they dependent on other factors, such as internationalisation and participation in the corporative system? Table 2 presents the results of regression analyses of individual elite members' support for the three important elements in the Norwegian model. The regression models include the independent variables discussed above (elite sector, class 
TABLE 2

NORWEGIAN TOP LEADERS' VIEWS ON MAIN ELEMENTS IN THE NORWEGIAN MODEL

\begin{tabular}{|c|c|c|c|}
\hline & $\begin{array}{l}\text { Model 1 } \\
\text { The welfare } \\
\text { state }\end{array}$ & $\begin{array}{l}\text { Model } 2 \\
\text { Centre vs } \\
\text { periphery }\end{array}$ & $\begin{array}{c}\text { Model } 3 \\
\text { The system of } \\
\text { centralised wage } \\
\text { determination }\end{array}$ \\
\hline Intercept & $3.144 * *(0.257)$ & $3.457(0.274)^{* *}$ & $3.216(0.303)^{* *}$ \\
\hline \multicolumn{4}{|l|}{$\begin{array}{l}\text { Elite group (reference group: } \\
\text { church leaders): }\end{array}$} \\
\hline $\begin{array}{l}\text { Leaders in the state } \\
\text { administration }\end{array}$ & $-0.146(0.117)$ & $-0.740(0.124)^{* *}$ & $-0.378(0.140)^{* *}$ \\
\hline $\begin{array}{l}\text { Leaders in culture } \\
\text { institutions }\end{array}$ & $-0.047(0.123)$ & $-0.650(0.131)^{* *}$ & $-0.281(0.147)$ \\
\hline Leaders in mass media & $-0.347(0.134)^{* *}$ & $-0.859(0.143)^{* *}$ & $-0.300(0.159)$ \\
\hline Leaders in private business & $-1.136(0.114)^{* *}$ & $-0.980(0.122)^{* *}$ & $-0.444(0.136)^{* *}$ \\
\hline Leaders in cooperatives & $-0.489(0.166)^{* *}$ & $-0.202(0.177)$ & $-0.133(0.197)$ \\
\hline Leaders in public enterprises & $-0.705(0.150)^{* *}$ & $-1.018(0.159)^{* *}$ & $-0.510(0.177)^{* *}$ \\
\hline $\begin{array}{l}\text { Leaders in interest groups } \\
\text { and voluntary } \\
\text { organizations }\end{array}$ & $-0.318(0.118)^{* *}$ & $-0.620(0.126)^{* *}$ & $-0.394(0.141)^{* *}$ \\
\hline $\begin{array}{l}\text { Leaders in research institutes } \\
\text { and universities }\end{array}$ & $-0.122(0.118)$ & $-0.515(0.126)^{* *}$ & $-0.368(0.141)^{*}$ \\
\hline $\begin{array}{l}\text { Leaders in police and the } \\
\text { judicial system }\end{array}$ & $-0.378(0.128)^{* *}$ & $-0.5537(0.137)^{* *}$ & $-0.446(0.153)^{* *}$ \\
\hline $\begin{array}{l}\text { Leaders in the military } \\
\text { services }\end{array}$ & $-0.538(0.138)^{* *}$ & $-0.364(0.147)^{*}$ & $-0.421(0.164)^{*}$ \\
\hline Politicians & $-0.054(0.130)$ & $-0.236(0.139)$ & $-0.363(0.155)^{*}$ \\
\hline \multicolumn{4}{|c|}{$\begin{array}{l}\text { Class background (ref. category: } \\
\text { upper and upper middle class): }\end{array}$} \\
\hline Middle class & $0.076(0.045)$ & $0.040(0.048)$ & $0.119(0.053)^{*}$ \\
\hline Working class & $0.182(0.054)^{* *}$ & $0.058(0.0$ & $0.145(0.064)^{*}$ \\
\hline $\begin{array}{l}\text { Member of public committee } \\
\text { or board }\end{array}$ & $0.107(0.044)^{*}$ & $0.009(0.047)$ & $0.048(0.052)$ \\
\hline $\begin{array}{l}\text { Frequency of contact with } \\
\text { other elite groups (aver.) }\end{array}$ & $-0.061(0.048)$ & $0.039(0.052)$ & $0.035(0.057)$ \\
\hline $\begin{array}{l}\text { Amount of time spent on } \\
\text { international contacts }\end{array}$ & $-0.0015(0.0016)$ & $\begin{array}{r}-0.0057 \\
(0.0017)^{* *}\end{array}$ & $-0.002(0.002)$ \\
\hline \multicolumn{4}{|l|}{$\begin{array}{l}\text { Area of contact (dummy } \\
\text { variables): }\end{array}$} \\
\hline The Nordic Countries & $0.056(0.057)$ & $0.006(0.061)$ & $-0.014(0.068)$ \\
\hline West Europe & $-0.122(0.046)^{* *}$ & $-0.134(0.049)^{* *}$ & $-0.086(0.054)$ \\
\hline USA and Canada & $-0.100(0.064)$ & $-0.052(0.068)$ & $-0.189(0.075)^{*}$ \\
\hline Africa & $0.297(0.120)^{*}$ & $0.053(0.127)$ & $0.197(0.141)$ \\
\hline $\begin{array}{l}\text { Controlled for age, gender } \\
\text { and education }\end{array}$ & Yes & Yes & Yes \\
\hline $\mathrm{R} 2$ & & 0.15 & 0.05 \\
\hline $\mathrm{N}$ & 1397 & 1395 & 1388 \\
\hline
\end{tabular}

Regression analyses (Ols).

Standard deviations in parentheses.

background, participation in the corporatist system, and international contacts), and the three control variables: gender, education and age.

The most striking finding in Table 2 is that the opinions of the leaders are particularly related to which elite group they belong to. This is true for the two first indicators of the Norwegian model. Elite group membership alone explains for instance as much as 24 per cent of the variation in the top 
leaders' attitudes towards the role and responsibilities of the state, while explained variance increases by only six percentage points when the other independent variables are added. The increase in $\mathrm{R}^{2}$ is even more modest in the second model (the leaders' views on economic transfers to the rural areas) - as little as one per cent. However, and somewhat surprisingly, 'sector' explains just one per cent of the variation in the leaders' attitudes towards centralised wage determination, while the remaining variables explain four per cent. This last finding reflects much stronger agreement among the various elite groups in their evaluation of this element of the Norwegian model.

Table 2 indicates, secondly, that top leaders' class origin has some, albeit relatively weak, effect on how they view the Norwegian model. Top leaders with working class background show greater approval of the welfare state model. Together with leaders from middle class backgrounds they also show greater support for the system of centralised wage settlement than leaders with a background in the upper or the or upper middle class. Class origin does not seem to have any effect upon their opinions on policies for preserving the rural areas.

Third, the first column in Table 2 confirms that top leaders who have been members of a public committee or board during the previous five years are more in favour of a continued active state than leaders without this experience. This variable did not affect their attitudes toward the centre/ periphery issue and centralised wage determination. Frequency of contact with representatives of other elite groups had no significant effect.

Finally, Table 2 indicates significant, although weak effects of internationalisation. The amount of time spent on contact with organisations or persons in other countries has impact only upon their evaluation of centre/ periphery compromises. International relations seem to instil a stronger central orientation among members of the Norwegian elite groups. Moreover, the areas of the world with which they have contact are also significantly related to their beliefs. Top leaders who have much contact with persons and organisations in Western Europe (outside the Nordic countries) endorse more privatisation, a halt in public welfare expenditures and a curtailment of state influence in private business (Model 1); and they are significantly less enthusiastic about continuing the economic transfers to the rural areas (Model 2). Top leaders with relations mainly to the USA and Canada are more negative to the centralised system of wage determination than leaders without relations to these countries (Model 3). But there is also a reverse effect of internationalisation. Among the few top leaders with main contacts with Africa, there is more concern with continuing the present welfare state model.

The result from the regression analysis is that 'sector' is by far is the most influential factor on social and political views. This implies that the elites in a modern society are first and foremost 'agents' or representatives of specific institutions. The findings from the German and Swedish elite studies 
support the same interpretation for these countries as well. As discussed above, the elites have been delegated authority by citizens, shareholders, or members to make decisions on their behalf which may enhance their welfare or meet their interests, and to see to the fulfilment of the basic purpose of the individual elite institution. Top leaders have power, but they must use their power in accordance with the specific institutional concerns, demands and norms. Understanding and explaining their attitudes and behaviour requires understanding of the institutions they represent.

\section{Discussion}

Influence from international trends, as well as substantive changes in politics and the economy inevitably bring forth social change. But is it a question of drastic change or more modest adjustment? Our results indicate that the majority of the Norwegian elites still support the basic institutions and policies in the Norwegian welfare state model and the political compromises upon which they are based (at least in the year 2000). They express strong support for the system of centralised wage settlements, a main element in the industrial relations system. They rally behind continued economic transfers to the districts. A majority (albeit small) of the elite groups prefers to uphold the present state model of production and distribution of welfare services.

Is this pattern of elite support specific to the Norwegian case, or is it similar to the situation in the other North European welfare states? The few available studies in Sweden and Germany (including Bürklin, Rebenstorf u.a. 1997) indicate that also in these countries a majority of the national elite groups are in favour of the present welfare state model. As top leaders of the institutions which constitute the fabric of this model, many of the elites have become caretakers and defenders of the model. This fact is conducive to a certain institutional inertia in the whole system. This state of affairs probably bolsters the welfare state model.

The wide range of attitudes of the political parties in parliament and their location towards the extremes, particularly on the index representing the private/public cleavage, is in accordance with 'the directional theory' of voting (Rabinowitz and McDonald 1989). According to this theory, the electorate will vote for that political party which most clearly shows them the direction in issues of particular importance to them. As a result of this role of political 'guides', the political parties take more extreme positions than the voters, including members of the other elite groups.

Above we pointed out that the elite structure in the Norwegian society has changed through the inclusion of 'new' elite groups. We particularly emphasised the mass media and the academic elites. Both of these elite groups turn out to be pronounced supporters of the Norwegian model. Thus, the change of the elite structure through the emergence of new elite groups has implied a fortification of the alliance behind this model. 
Moreover, the mass media and the academic elite have been accompanied by the church leaders. During recent decades a change of mentality seems to have taken place within the church. Once a rather politically conservative group, i.e. belonging to the right wing of the political landscape, the church elite has become virtually a spearhead in the support for the welfare state and the rural districts.

When we consider the three dimensions of the Norwegian model together, it appears as if the private business elite stands relatively alone in their preference for significant changes in this model against the rest of the elite groups. Business leaders are strongly in favour of reducing taxes, downsizing the public sector and curtailing state influence upon private business. They believe that the redistribution of income in Norwegian society has been taken far enough, and that it is time to reconsider incomes policy and regional policy. Even if a majority of those in our study expressed a will to continue the centralised of wage settlements, the Norwegian Confederation of Industry and Trade has recently decided to go for a more decentralised system.

Hence, the most important source of a push for change in the Norwegian welfare state model is found among the private business elite and political parties sympathising with their position. Admittedly, private business leaders represent a minority within the Norwegian elite, but they have considerable power. One basis of their power is the possible threat to eliminate jobs through shutting down or downsizing production or moving to other regions and countries (Lindblom 1977). They also have considerable argumentative power, and actively use it to influence the outcome of political decisions. Employer and private business organisations, as well as individual top leaders, are among the most active lobbyists in the Norwegian political system. In total, all these lobby activities amount to a significant pressure upon the political decisions-makers in Norway (Gulbrandsen et al. 2002).

This description of the private business elite as the most important 'agent for change' in Norwegian society needs to be moderated. Firstly, as shown above, the members of this elite group strongly approve of the Norwegian system of industrial relations. In fact, they are less worried about any negative effects of this system than many right-wing politicians. They have a relatively strong trust in the main political and social institutions of the society, on a par with the other elite groups, testimony to a significant adherence to the institutional basis of Norwegian society (Engelstad et al. 2003). Moreover, in the 1997 parliamentary election about 20 per cent of business leaders voted for a socialist party, indicating that independent of their general ideological beliefs they may be pragmatic in action (Gulbrandsen 2005).

Even though the business elite has considerable power within their own half of the field - to decide about investments and location of production their power is limited in significant ways. One important limitation is due to 
collective action problems. Modern Norwegian history is full of examples of business leaders who on the one hand have ideologically and politically combated state interventions, but on the other have actively lobbied for public subsidies or regulations giving themselves favourable market conditions or protection. Business leaders basically seem to be characterised by a 'both-and' orientation. They want the best out of the state, while simultaneously advocating a liberal market model of political governance.

Moreover, the power of the business elite is limited by their position vis-àvis the other elite groups. In many respects their views and preoccupations have been shown to be fairly remote from those of other elites. With the exception of conservative politicians, they have hardly any natural allies in the other elite groups.

Are there any 'countervailing powers' or mechanisms which work to the advantage of the present welfare state model? The present model is particularly defended by those elite groups which manage ideas and general values, i.e. church leaders and the top leaders within the academic, mass media and culture sectors. The future of the Norwegian model may then depend upon the willingness and ability of the members of these groups to develop and disseminate alternative ideological ideas and arguments in favour of the model.

Likewise, civil servants in the state bureaucracy and the judicial elite (judges and top leaders within the police) both support the main elements of the Norwegian model. At the same time, members of the judicial elite have the most privileged social background of all elite groups. Civil servants, as well, are frequently recruited from the upper class and the upper middle class. It might seem a paradox that these privileged groups nonetheless take their stand behind the Norwegian model. One possible explanation is that as public sector employees they are personally highly dependent upon the continuance of this model. In our opinion, this finding can be better explained by examining the basic values and culture of the institution to which these elite groups belong, the state civil service.

In the second half of the nineteenth century the Norwegian state, in spite of a liberal orientation, had to step in to safeguard the emerging industries, investing heavily in the infrastructure and assisting the establishment of a national banking system. In this manner the state became a 'senior partner' to private business. This fact is evidence of the historical role of the civil servants as managers and overseers of the collective interests of the emerging nation. In many ways the state bureaucracy and its top leaders became a pillar in society, creators and stewards of the basic institutions in the new nation. This role and the ensuing obligations created an ethos of moderation and loyalty to the constitution, which is still alive.

A characteristic of the system of political decision-making in Norway, as in the other Scandinavian countries, is that significant interest groups are involved in preparing and implementing political decisions. They are frequently consulted before final decisions are made, and they act as 
members of numerous public bodies. To a large extent, this corporatist system emerged as a response to the serious class conflicts during the first decades of the twentieth century. Our findings indicate that an indirect effect of this system is to increase the support for the present welfare state model.

Coping with the challenges to the Norwegian model is, of course, not confined to the elites alone. The future of the model depends equally upon the attitudes and reactions at the mass level. Citizens may put pressure on the elites to continue the present level of the welfare state, or they may favour fundamental changes. Available data, referred to above, testify a strong popular adherence to the welfare state based on public services. A crucial question is to what extent elites reflect the preferences in the population.

We have shown that a democratisation of elite recruitment has taken place over the last generation. Even though the recruitment pattern is far from egalitarian, this has obvious consequences for the adherence of the elites to the Norwegian model. To some degree, top leaders of lower social origin are more supportive of central elements in the Norwegian model than elite persons from the upper and upper middle classes. The effect is, however, fairly weak, something which implies that increased openness will have modest consequences. Equalisation of chances to reach elite positions is a good thing in itself, but more for reasons of democracy than for the defence of the welfare state.

Our diagnosis is that in the immediate future the elites will not attempt to push the population to accept significant changes in the Norwegian model. To the extent that this model encounters serious difficulties, the challenges lie in coping with collective action problems and problems of governance, rather than in differences in values and preferences between citizens and the majority of the elites.

\section{Notes}

1. This study is an important part of the Power and Democracy Project, a five year project commissioned by the Norwegian parliament. The Leadership Study was conducted by the Institute for Social Research in collaboration with Statistics Norway.

2. On the basis of the replies we constructed an index with values from 1 to 4 , where 4 indicates little support for the present 'welfare state model'; the value 1 indicates very strong support. Cronbach's alpha $=0.81$.

3. On the basis of the replies an index was constructed in the same way as the private/public index with four values. Cronbach's alpha $=0.61$.

4. The construction of this variable is described in detail in Gulbrandsen et al. (2002).

5. The groups were: (1) members of parliament, (2) members of the cabinet, (3) leaders of the political parties, (4) top leaders of the ministries, directorates and inspectorates, (5) leaders in private enterprises and finance institutions, (6) leaders in public enterprises and finance institutions, (7) leaders of national trade unions, (8) leaders of employer and trade associations, (9) national leaders of voluntary and civic organisations, (10) leaders of universities, colleges and research institutes, (11) church leaders, (12) leaders within the 
police and the judicial system, (13) top officers in the military services, and (14) editors and senior commentators in the mass media. The questions about contact with members of the Storting and the cabinet were not presented to permanent secretaries, general directors, ambassadors, members of the Storting or secretaries of state, and the alternative replies were weekly, monthly, less frequently, or never.

6. Seventy-seven per cent of the leaders reported that most of their contact was with the Nordic countries, 68 per cent replied Western Europe, 17 per cent USA and Canada, and only 3 per cent had most of their contact with persons and organisations in Africa.

7. First, a smaller sample size in the 1967 data may imply a somewhat greater concentration of persons with elite background. Secondly, while the Leadership Study 2000 used survey questions to collect information about the social background of the elites, Higley, Field and Grøholt (1976) availed themselves of standard sources of data such as Who's Who, handbooks of various occupational and professional groups and yearbooks of university student cohorts. Third, even though the class variable has nearly identical labels in the two data sets, the underlying classification of occupation is not identical. In the study by Higley, Field and Grøholt (1976) the business elite sample consisted of 325 persons who held directorships and executive positions in the 122 largest private companies and the six most central business organisations and about whom relatively uniform data were available. In the 2000 study the business elite consisted of the CEO or president and the chairman of the board of all private companies with at least 400 employees (238 companies), and the vicepresidents in enterprises with more than 4,000 employees (24 companies). The political elite in the 1967 study consisted of the 79 persons who held cabinet or under-secretary positions and the 97 persons who sat on the national executive committees of the five political parties. In contrast, the sample of political leaders in the 2000 study consisted of members of parliament, cabinet members and their under-secretaries, leaders of the political parties and the mayors in the ten largest cities in Norway. Even if the 1967 study did not specifically select members of the Storting it still covered this group of politicians indirectly because most of the persons in their sample had high parliamentary positions throughout most of the 1960s. The sample of the civil service elite in the 1967 study was put together in a very similar manner to that in the Leadership Study 2000.

\section{References}

Barth, Erling, Kalle Moene and Michael Wallerstein (2003). Likhet under press. Oslo: Gyldendal Akademisk.

Bürklin, Wilhelm, Hilke Rebenstorf u.a. (1997). Eliten in Deutschland. Opladen: Leske+ Budrich.

Christiansen, Peter Munk, Birgit Møller and Lise Togeby (2001). Den danske elite. København: Hans Reitzels forlag.

Engelstad, Fredrik, Trygve Gulbrandsen and Øyvind Østerud (1999). 'Elite Compromises in a Stable Democracy: The Case of Norway', paper for the Annual Meeting of the American Political Science Association, Atlanta, 1-5 September 1999, http://www.sv.uio.no/mutr.

Engelstad, Fredrik, Espen Ekberg, Trygve Gulbrandsen and Jon Vatnaland (2003). Naringslivet mellom marked og politikk. Oslo: Gyldendal Akademisk.

Gulbrandsen, Trygve (2005). 'Ideological Integration and Variation within the Private Business Elite in Norway', European Sociological Review, in press.

Gulbrandsen, Trygve, Fredrik Engelstad, Trond B. Klausen, Hege Skjeie, Mari Teigen and Øyvind Østerud (2002). Norske makteliter. Oslo: Gyldendal Akademisk.

Higley, John and Michael G. Burton (1989). 'The Elite Variable in Democratic Transitions and Breakdowns', American Sociological Review, 54, 17-32.

Higley, John, G. Lowell Field and Knut Grøholt (1976). Elite Structure and Ideology. A Theory with Applications to Norway. New York: Columbia University Press. 


\section{T. Gulbrandsen and F. Engelstad}

Hoffmann-Lange, Ursula, Helga Neumann and Bärbel Steinkemper (1985). 'Conflict and Consensus among Elites in the Federal Republic of Germany', Research in Politics and Society, 1, 243-83.

Katzenstein, Peter J. (1985). Small States in World Markets: Industrial Policy in Europe. Ithaca, NY: Cornell University Press.

Lindblom, Charles (1977). Politics and Markets. New York: Basic Books.

Lijphart, Arend (1969a). The Politics of Accommodation. Berkeley: University of California Press.

Lijphart, Arend (1969b). 'Consociational Democracy', World Politics, 21, 207-25.

Listhaug, Ola, and Torill Aalberg (1999). 'Comparative Public Opinion on Distributive Justice', International Journal of Comparative Sociology, 40, 117-40.

Mills, C. Wright (1956). The Power Elite. Oxford: Oxford University Press.

Petersson, Olof, Jörgen Hermansson, Michele Micheletti and Anders Westholm (1996). Demokrati och ledarskap. Stockholm: SNS Förlag.

Presthus, Robert (1973). Elite Accommodation in Canadian Politics. Toronto: McMillan.

Putnam, Robert D. (1976). The Comparative Study of Political Elites. Englewood Cliffs NJ: Prentice-Hall.

Rabinowitz, George, and Stuart Elaine MacDonald (1989). 'A Directional Theory of Issue Voting', American Political Science Review, 83, 93-121.

Ruostetsaari, Ilkka (1993). 'The Anatomy of the Finnish Power Elite', Scandinavian Political Studies, 16, 305-37.

Schnapp, Kai-Uwe (1997). 'Soziale Zusammensetzung von Elite undBevölkerung-Verteilung von Aufstiegschancen in die Elite im Zeitvergleich', in Wilhelm Bürklin, Hilke Rebenstorf u.a. Eliten in Deutschland. Opladen: Leske + Budrich.

Siaroff, Alan (1999). 'Corporatism in 24 Industrial Democracies: Meaning and Measurement', European Journal of Political Research, 36, 175-205.

SOU (1990): 44. Makt och demokrati i Sverige. Maktutredningens hovudrapport. Stockholm.

Woldendorp, J.J. (1995). 'Neo-corporatism as a Strategy for Conflict Regulation in the Netherlands (1970-1990)', Acta Politica, 30, 121-51.

Öberg, Per (2002). 'Does Administrative Corporatism Promote Trust and Deliberation?', Governance: An International Journal of Policy, Administration and Institutions, 15, 455-75.

Østerud, Øyvind, Fredrik Engelstad and Per Selle (2003). Makten og demokratiet. Oslo: Gyldendal Akademisk. 